\title{
How do females deal with hindrances in School Headship? Evidences from the Ivorian Context
}

\author{
Rassidy Oyeniran, PhD \\ Department of Science Education, Institut Pédagogique National de \\ l'Enseignement Technique et Professionnel, Côte d'Ivoire
}

\section{Zhang Lili, PhD}

Faculty of Education, Beijing Normal University

Institute of Education Theories, China

Doi:10.19044/ejes.v7no2a8 URL:http://dx.doi.org/10.19044/ejes.v7no2a8

\begin{abstract}
Leadership, particularly, that of school principals is one of the most important concerns in the field of education. Constantly, studies have shown that women educational leaders effectively lead their schools. Yet, the stories behind how a woman leads a primary school and experiences, challenges and barriers in the principalship have not received adequate exploration in Ivorian context. The purpose of this study is to critically investigate the difficulties and obstacles faced by Ivorian women school principals from the gender equity perspective. Ten (10) women school heads took part in the study. Qualitative method was used to gather data through in-depth semi-structured interviews. The findings show that cultural and structural factors, and workhome role conflicts are the main barriers affecting women and their headship in school management. The study concludes that the women leaders have to deal with these hindrances, to surpass many other constraints and issues that occur within their schools and to keep working. For this to happen women principals needed to be creative. This would also be possible through a necessary transformation of structures along with reformed policies in increasing the recruitment of women for the school headship.
\end{abstract}

Keywords: Women principals, primary schools, principalship, challenges, Côte d'Ivoire. 


\section{Introducing the context and the research problem Background}

Women under-representation in positions of principalship and their challenges are still misrecognised, and seem to be ignored in Ivorian basic education. Although several conventions such as the Millennium Development Goals (MDGs), the Convention against discrimination in Education, the Convention on the Elimination of All Forms of Discrimination against Women (CEDAW), the Dakar Framework for Action, Education for All (EFA) have been ratified and adopted (Assié-Lumumba, 2006) and affirmative action policy of females has been hailed as a milestone in their emancipation, there are limited studies as regards women experience in leadership.

Besides, women continue to undergo discriminatory treatment and subordination despite the existing of many international and regional conventions on the legal documents (such as International Conference on the Population and the Development of Cairo in 1994 and the Beijing Conference in 1995) that protect women against harmful treatments and discrimination). Although the Constitution of 2015 clearly declares the empowerment of Ivorian women, the gap in gender parity persists. The country has 22671331 inhabitants, from which men represent nearly 11708244 (51, 6\%) and women 10963087 (48, 4\%) (INS, 2017). Illiteracy in Côte d'Ivoire is about 43, 8\% of which women are 53\% (INS / MICS, 2016). More than 35\% of Ivorian women in the farm and only $10 \%$ are educated (Moreau, 2014).

Moreover, gender stereotypes stemming from the patriarchy confine most women in so-called feminine low-qualified and low-paid jobs and sectors. Most of illiterate women live in rural areas. More specifically, in educational leadership settings the underrepresentation of women is obvious. In May 2017, men were 13837 while women were 1710 or $11 \%$ of total 15547 primary school principals (MOE, 2017).This situation of women in Côte d'Ivoire is problematic and bring about issues that need further exploration.

Despite the existence of affirmative action and numerous regional and international conventions ratified by the Ivorian government to promote and achieve gender equity, Ivorian women in educational leadership still experience challenges, including personal, professional and structural obstacles. Beyond challenging situations, women principals strive to manage their schools, keeping in mind that pupils deserved consideration.

In educational settings, leadership has been seen as a key factor in school effectiveness (Mollel \& Tshabangu, 2014), while leadership has been and is still associated with masculinity and male stereotypes continue to dominate the perception of leadership (Klenke, 1996). It is currently observed that women running primary education institutions face serious challenges in 
their day-to-day actions that mainly stem from patriarchal values and norms, cultural and structural entrenchment in society and schools in particular.

Women in Ivorian basic education and in primary schools particularly appear to be discriminated and undermined (Oyeniran, 2018). Besides, in addition to being low-represented in leadership positions, the few women who assume principalship roles experience a number and complex challenges and hindrances. Some of the major challenges and obstacles discussed in this paper include the social roles and gendered nature of management practices and work-family issues. The research was the opportunity to raise the unheard voices of women school principals and to help eliminate, if not to reduce socio-cultural and structural barriers for the advancement of women in school leadership positions. For looking at the issue critically, the objectives of this study open the scene.

\section{Objectives of the Study}

This study seeks to shed light into the lived experiences of women educational leaders and create an awareness of the existing issues in schools. In particular, it intends to assess the challenges that hinder these women leaders in their efforts to perform their principalship and overcome barriers. Besides, this study aims to bridge the gap in research on women in educational leadership positions and gender issues not only within the Ivorian context. It will expectantly contribute to the growing body of knowledge on education and gender awareness in schools, and be useful to those in leadership positions, and those who write policy and leadership development programmes within the basic education and beyond. The importance of this is that it suggests an appeal for a closer attention to a limited field of study.

The summarized objectives of the present study are the following:

Explore the major challenges encountered by women in school leadership positions

- Uncover the leadership experiences of women principals, looking at their coping strategies to deal with challenges and barriers

\section{Literature review}

\section{The socio-historical engagement of women as leaders}

Traditionally, African women held a significant function in the society. She worked within the community/society as an agent of economic development and stability. Moreover, she was essential because she played several functions at a time; she was an agent of biological reproduction and political commitment. She was the one who 'create' humanity, and was a force ensuring the survival of the social group.

Likewise, it has been proven that women can play historical and valuable roles in the society. As an example, women have demonstrated their 
obstinacy and bravery in the Sudanese and Eritrean wars to the benefit of their communities. In her essay "Memory work as resistance: Eritrean and Sudanese Women in Conflict Zones", Hale (2012) reported a counter-story of the women's heroic roles. She demonstrated how in conflict situations women positioned themselves as agents of resistance in the context of both the Eritrean and Sudanese wars. The scholar discussed ways in which women used their memory to express their own roles in resistance work. The ways in which women insisted on remembering, in very particular ways, their own roles in resistance work. Women warriors were able to use repeated gestures to recall the social injustice they undergone. Hale interpreted women's political memory work. Actually, the individual memory of women contradicted the official memory, which did not consider individual memory. It assumed everyone had a similar experience and had moved on. Yet, that memory work sometimes runs counter to the official story of the state, the party, or even the resistance group, as women were the ones who could narrate accurately the realities of their life stories. Thus, it was worth giving voice to the women who were involved in the conflicts to gain the actual versions of their lives at the times of conflicts.

As the Ivorian people are a deeply agrarian people, women have always been fully involved in agricultural and food production. Sociologically, the Ivorian woman is remarkably a worker in the service of her community. According to Touré Ténin, more than $80 \%$ of women are farm workers, and they represent nearly $75 \%$ of the agricultural workforce in Côte d'Ivoire (Touré, Kouassi, Lagou, Dahoure, \& Fofana, 2017). Woman bears the responsibility for the early education of the child in the African community. She is a "vector" of alliance between the family and the society in which she lives. Among those African women who played leadership roles in their communities and influenced society greatly, are Yaa Asantwaa of Ghana, the Queen mother of Ejisu in Ashanti and Zhinga Queen of Matamba in Angola, Abla Pokou from Baoule tribe in Côte d'Ivoire (Oyeniran \& Bonjah, 2018). In ancient and modern Ivorian societies, great emblematic figures such as Anne Marie, Abla Pokou, Marie Kore and Jeanne d'Arc have marked the history of Côte d'Ivoire as fierce political fighters for the liberation and independence as well as the "architects" of the construction of the Ivorian Nation. Even if Ivorian women have been of a great important in the past, today as leaders they experience challenges in many sectors, including education settings. Generally that comes from being considered as subordinate in their communities. 


\section{Subordination of Women}

Several cultural, political and socio-economic factors explain the inequalities. Very often, the cultural factor is put forward as the main cause of discrimination and inequality suffered by Ivorian women. Indeed, the precarious and informal nature of women's work can be explained by the patriarchal system that conveys a gender division of labor based on two principles: the principle of separation and the principle of hierarchy. The first assigns men primarily to the productive sphere and women to the reproductive sphere. According to the second, a man's work is worth more than a woman's work. As a result, we can better understand why, despite the existence of job opportunities, women are excluded or reduced to precarious or marginal jobs. Worse, in the education of children, it is these same female victims who transmit to their offspring this culture of the gender division of labor and the domination of boys over girls, maintaining the system of discrimination. Up to now that seems not release females from work and domestic duties.

\section{Work-Family Issues}

When women are leading organizations, they often strived to work harder to prove their capabilities, especially in the male-dominated workplace. Men are considered to be decision-makers and these patriarchal societies are still uncomfortable seeing women in political decision-making positions. Even though women rise to hold level positions, men may still make decisions.

Traditionally, giving birth and taking care of children remains the big picture of a woman in Ivoirian societies. This perception is mainly informed by persistent cultural and traditional stereotyping towards women who, therefore, are expected to just serve as caregiver and accept decision made by men. Women who move outside these traditional roles are considered nonfeminine, wearing pants and not eligible for marriage. The majority of women who are in key positions are either single or divorced (Andela, Escandon, Garlo, \& Kamungi, 2008). It is generally, proven that work-family balance remains difficult for women. For them, it is important to pursue an ideal of life, not to compromise on values and on the family concerns. However, that may request from them to have the courage of their beliefs and ideas, to take care and make sure they are stable and leave room for their passion, enthusiasm and desire.

It seems that the pressure and burdens may lead many women feel reluctant to take up jobs, which would separate them from their families. However, once engaged in the principalship women primary school principals might deal with a number of challenging experiences during their professional career. How to balance between family attachment and family roles and work needs remain one of the major challenges for women. 
In education and more specifically in the context of primary schools, the needs of students and parents are more expressed and complex. Managing individual cases of students, having meetings with the educational community and attending meetings outside the school with the superintendents (Inspectors, School Counsellors, Chief Administrative Officers, and Chief Executive Officer) consume time and energy. Especially, it may be challenging for a woman principal who must also fulfil her family needs and duties, especially when she has to look after children at young age. The conflict between work and family responsibilities can be hard to women who have to accomplish double roles as homemaker and principal (Coronel, Morena\& Carrasco, 2010).

The issue of balancing personal life, children and work requirements are seen as the most common barrier that women face, that is why some researchers (Kellerman \& Rhode, 2007) have found that women, most time, drop leadership roles and focus mainly on their family concerns, which in turn disturb their professional career. In Côte d'Ivoire, women are considered the "mother of all"; that is to say not only responsible for their family, extended family, but often also for neighbours and community members (Andela et al., 2008). Women are generally confronted with the challenge/dilemma of having to balance a multiple roles: administrative, teaching and home roles. They are expected, primarily, to be responsible for the family and managing the home. Society expects from women to be responsible for the family and home business. Early in life women are expected to take on the responsibilities of caring and supporting their families (for example, taking care of their parents or assisting in earning money to pay for a brother's school fees). These responsibilities can be quite heavy, hard and often deny women important experience and access to strategic information. Regarding stereotypes, it can be argued that, in Côte d'Ivoire all those social roles and stereotypes towards women, including women principals, influence their headship and lead them to struggling in leadership positions. To reach evidences of this, a theoretical lens leads the study.

\section{Theoretical perspective}

The framework that guides this paper is feminist theory (Gilligan, 1982; Harding, 1987). This perspective is deemed suitable and interpretive to help for critically understanding experiences, working conditions and challenges from women's voices and leadership styles adopted by women principals. Besides, it brings to the surface voices that are often excluded from knowledge production and policy making, and critically reflect upon how it can all be done better (Frisby, Maguire \& Reid, 2009).Hesse-Biber (2012) suggests that feminist approach stresses the importance of giving voice to women pointing out their marginalized position in terms of gender; and 
recognizing women's life stories as knowledge from the schools context. In fact, feminist research is seen as being concerned with issues of broader social change and social justice and committed to changing the condition of women (Acker, Barry \& Esseveld, 1983; Fonow \& Cook, 2005). This study therefore, look at the challenges faced by women principals as shared issues frequently experienced in the principalship.

Thus in this study, the feminist approach includes all arguments criticizing the inequalities against women principals in order to improve their professional conditions. Besides, feminist theory considers gender as a social, historical, and cultural construct (Gilligan, 1982; Harding, 1987; Butler, 1999; Connell, 1995; Reinharz, 1992; Reinharz, 2006). In light of this, the use of feminist theory in this study offers insight into the social construction of gender and perception of women principals' capabilities in leadership positions. Furthermore, women leaders express their own experiences and share their perceptions about their leadership styles, which may critically serve feminist theories and research. The concern of feminism and feminist research is to construct knowledge that "writes women into history and exploring, challenging, resisting and changing sexual and social inequalities" (O'Neill, 1996, p. 131).

Feminist research is concerned with studying the issues facing women at its starting point, and it seeks to search and explore the social dynamics and relationships in patriarchal society from women's perspective (Hussain, \& Asad, 2012, p. 206). As such, feminist research considers women's viewpoint, experiences, needs and thoughts as the base of the research with the aim of bringing social changes and eliminating gender bias in the society. Through this perspective the researchers sought to promote equality in the research process through the accounts of women's experiences that may contribute to enact social change and transformation in the context of schools in mainland of Côte d'Ivoire. The next lines present a suitable methodology to explore the lived leadership experiences of these female primary school principals through a phenomenological approach.

\section{Methodology}

This study used qualitative research design to examine the challenges through the leadership experiences of women principals and to develop a deeper understanding of principalship and how they experience it (Creswell, 2013). Basically, this study used qualitative approach as it aimed to capture the first-hand accounts of the women lived leadership experience and perceptions (Creswell, 2013). This has the advantage of stressing the rich contextual detail and women leaders' experiences to gain holistic and meaningful information about the opinions, emotions, attitudes, nature of 
relationships of school boards and the actual professional context of the participants.

Ten (10) women school heads was identified using sampling technique. The women selected were from ten (10) elementary schools located in Abidjan, in the South of Mainland Côte d'Ivoire, which is the economic Capital city (Abidjan). Two out of these ten women principals were selected using purposeful convenience strategy, and the rest were found by snowball sampling technique (Creswell, 2013). As this study is a case study, it concerns women principals performing in the real life that could be observed/studied to learn about their lived experiences (Yin, 2014). The case study allowed the researchers to explore all three domains of the interviewees (women principals), which are cognitive, behavioural and affective (Leedy, 1980). Qualitative data was collected through in-depth semi-structural interviews, direct observation and secondary data (existing literature \& official documents). The women principals were given the opportunity to tell their stories in a narrative way. In addition to semi-structured interview, the researchers utilized direct observation to take note from the fieldwork. A voice recorder was used and participants were identified with pseudonyms.

A phenomenological approach helps to gain access to women's lived experiences, to capture the first-hand accounts of their perceptions of leadership as principals, from their own perspective (Creswell, 2013). As this study is a case study, it concerns women principals performing in the real life that could be observed/studied to learn about their lived experiences (Yin, 2014). The study employed phenomenology approach because it aims at emphasizing the importance of individual experiences of the participants as conscious human beings (Moustakas, 1994) to identify the differences if any. In addition, the study intended to investigate women lived experiences to describe the common meaning of experiences and perceptions for all the respondents of which a central meaning of these accounts may come out.

The phenomenological approach thus allowed reconstructing the experience of the women principals while yielding validity to their narrative. Phenomenology remained as most as possible faithful to the data, while the researchers used thorough words through a few verbatim accounts. The N'Vivo data processing software (Pfaffenberger, 1998; Richards, 2006 as cited by Gaudreau, 2011; Van der Maren, 1996) helped to analyze the data. In this light, the verbatim accounts were digitized and stored. From there, the findings were deeply analysed. 


\section{Research findings}

Eight selected women principals took part in the interviews and provided some information of their biography that are placed in the table below.

Table 1. A brief summary of female principals' information

\begin{tabular}{llll}
\hline Pseudonym & Age & Marital status & Number of children \\
\hline Bella & 40 & Single & 1 \\
\hline Dany & 41 & Married & 1 \\
\hline Fiath & 39 & Single & 0 \\
\hline Gely & 43 & Married & 2 \\
\hline Paty & 45 & Divorced & 3 \\
\hline Thia & 40 & Married & 1 \\
\hline Sali & 42 & Married & 2 \\
\hline Suna & 47 & Married & 3 \\
\hline
\end{tabular}

Source: Fieldwork data

Through narrative women principals described their experiences including structural and cultural entrenchments in society as well as in schools. The daily activities are busy with a range of tasks. Principalship involves many responsibilities; the more women become immersed themselves in their role, the more tasks and issues they end up taking on. The women participants narrated their experiences in different ways.

\section{No time to save}

The first principal Suna started her story full of challenges. She shared what she experienced as troubles in her principalship. Suna confessed that the role of the principal is to manage everything; as principal "you are responsible for handling and updating teachers and students' files, teaching, attending meetings at the school inspectorate and doing daily routine". She further expressed this:

My work is tiring, stressful, especially for a woman like me who lives far away from my workplace, transportation issues as you know here in Abidjan city are very complicated and stressful and too expensive (...) the distance from my home to my school takes me long, about one hour. Principals like me do not have the opportunity as some others colleagues who are housed within the school. While I am requested to be on time every day... at times traffic jam makes me delayed; and as result, my pupils lose time of learning.

Women principals in this study felt that despite their willingness and sincere devotion, they could only just manage to squeeze administrative tasks into teaching loads and breaks. Sali, and Paty also revealed that they have been 
attending several meetings in a month at the inspectorate that takes too much time from their schedule. Almost all women leaders who took part in this study agreed that being absent from school to attend meetings at the school inspectorate, outside the school with NGOs, at the town hall or for networking with other stakeholders to solicit donations or financial support for their school, did not relieve them of their heavy jobs.

However, the delay in getting the school on time means a waste of time in the amount of their teaching time and the discontinuity of the syllabus content. That situation leads them to fix or complete the lessons overtimes, which at times coincide with other programs or unsuitable time. Suna, honestly, acknowledged that she cheated a bit at times in catching up with the schedule. She stated,

When I missed class I don't need any preparation sheet to teach, as I teach grade 1 whose syllabus remains the same each year, which is not too hard to be covered by the end of the year.

Avoiding time away from school and preserving the full time of teaching was the eager desire of all the women interviewed. Sali realized how the combination of principalship duties and teaching responsibilities brought about troubles in her work, as it upset the syllabus and the ongoing teaching every year, and at times weakens her full potential as woman leader. That's why women principals in this study wished the principalship was detached from teaching load, so that the school head will only focus on the whole school management, including administrative affairs, teaching supervision and pupils concerns, which would benefit them in their learning and performance.

\section{When the marriage is threatened}

Balancing work responsibilities and family duties bring about workfamily roles conflict as expressed most women principals in this study. The case of Gely who made an ultimate decision of living alone with her children is an eloquent example of a woman who resign herself to staying single. Actually, after losing her husband, she now strives to live up with her current status of an unmarried mother to avoid constraints and struggles of a married woman. She said, I have decided not to contract a new marriage because I was afraid of not being able to integrate family obligations with work responsibilities... You know, it is hard to balance work and home duties, so I did not want to put myself under pressure because of heavy duties.

In addition to her children, Gely had to take care of her husband after work. She felt being single mother didn't release her from her family responsibilities and household chores, as she henceforth lived alone and had to feed her kids, bring them up and schooled them.

Although these duties were still there, she got free from subordination and submission from her husband who gave her a sort of agent. Hence, having 
no husband was empowering, even if Gely had to fend for her family; the avoidance of the marriage again was for her an advantage. Engaging in a new relation would have submitted her to heavy load once she is in a marriage. That's why she preferred being single.

Unlike Gely and Thia do not perceive too much trouble to handle both of these responsibilities. Although, these women acknowledge the difficulty of managing, administrative responsibilities and family businesses they affirmed that they were able to balance both loads. Thia said:

It is a matter of how you organize, how you set your schedule, your planning every day, including the unplanned tasks (...) If you are well organized your family would not be affected by the work requirements. I do my best to organize my timetable, planning and other issues.

The above perception is not common to all women participants, regarding their different experiences as heads of schools. However, the rich accounts collected allow the researchers to discuss and interpret the meanings of the participants.

\section{Discussion}

From all that was described by the women principals, what emerged was that working conditions, complexity of tasks and challenges was seen as a resource of difficulties that women experienced. These suggest that leadership is a challenging process that requires coping strategies.

\section{Socio-cultural and institutional realities}

Indeed, evidence from the interviews showed that cultural perception on women principals affected their headship. Mostly in Ivorian contexts, women are expected to listen to men, neither to talk nor to make a decision on gatherings where men outnumbered women. Women are generally assigned the tasks of communication, assistance or secretariat to take note of and report on the meetings.

In fact, it is an instinctive habit that men have towards women, who themselves often appreciate such roles since they do not complain anyway. Yet the nature of the role assigned to women in decision-making instances hides men's control over meetings and the subsequent decisions. The reason of those men's attitudes can be found in cultural traditions, which still assign woman to be a follower of the man. Ivorian society still believes in gender taboo that does not accept a woman as leader. Society regards women as persons whose role is to be in charge of household chores and take care of children. Leila felt "leadership is still considered the preserve of men. There are people who still think only men can be good leaders".

This tags along with the thought that a man is supposed to be competent, to do his job well, which generally makes sense for people in 
Ivorian context. As for a woman, people will expect from her to prove herself. However, it is not obvious as such from the outset. When a woman is wrong, the stereotypical sarcasm flows. A man might be criticized, but not the same way. In fact, women are viewed differently in Ivorian societies. In the societal expectations, working in administration positions belongs to a man, yet that way of thinking yield affected negatively on women principals. This finding is in agreement with Coleman (2002) who reported that "the main genderrelated problem for the women heads was the resentment felt by men and some women about women in a leadership role, the underlying belief that leadership is inappropriate for women"( p. 87). In Côte d'Ivoire, cultural beliefs and practices have obstructed women empowerment due to the fact that people generally are socialized into accepting the norms, values and customs of social systems in which they grow up, and schools have likely played a major part in that process of socialization.

Actually, in Ivorian societies, gender socialization begins earlier, from birth and perpetuates until maturity for both girls and boys. In addition to cultural heritage, education from the childhood is also seen as an explanatory factor of people's attitude towards women, especially when interacting with men. From childhood, the little boy is socialized with the idea that he has to behave differently. He is told a boy does not cry, a boy is strong, a boy has not to be an emotional person, he has not to be weak. Thus, the little boy grows up with the idea that he must always be strong and should refuse to be influenced; and even when he encounters painful situations, he is forced to restrain himself.

However, one does not tell the little girl not to cry, people do not mind her and one does not tell her to control her emotions in difficult situations. It can be therefore asserted that in the communities, traditional beliefs and practices constitute the dominant hindrance to the promotion of women into administration positions.

\section{Patriarchal leadership structures}

Women principals experienced cases of confrontation and insubordination coming from the fact that males kept undermining women authority. Leila expressed, 'I have experienced resistance from a male teacher who expected me to fail in my administrative role"'. This finding is consistent with that of Mapolisa, Chibvonga and Madziyire (2013) who found that social and cultural factors intervene to form a barrier to Zimbabwean women's advancement, which is one of the reasons that tend to show that women leaders are not as successful as male leaders. This is the evidence that structural perceptions are heavily embodied in male minds, as teachers displayed disrespectful behaviours towards women principals. Gely revealed that a teacher from a patriarchal tribe challenged her for about three months before 
he left the school the previous year. Gely clarified, "I heard that teacher confessed to the other teachers that in his tribe women cannot order male to do something".

In Côte d'Ivoire, male outnumber women in the teaching profession and the principalship of primary school. For a woman, involving into space of male-dominated professions is perceived as a quite difficult mission because the culture is still strongly patriarchal. It seemed the matter lies in the cultural beliefs of organizations. Burke (2015) raised the ambiguity of the situation of women in the academic field. Burke noted that women might outnumber men at university, though numbers alone will not change gender inequality. It can be argued that cultural prejudice, stereotypes, moral and psychological oppression remain the greatest perceptions of the Ivorian communities, and they are particularly expressed in men's attitudes. For example, men happened to devise evil or do not easily accept to be run by a woman in school. In the mind of men, leadership is made for men, not for women. Generally, women capabilities are undermined at many workplaces, as revealed a study by the Global Observatory of Inequalities, at the global level, women earn on average 25\% less than men (Moreau, 2014). Actually, in Côte d'Ivoire, the average income of Ivorian women is lower than that of men. This is the actual situation in most private sectors. In the public sector, the discrimination towards women and the denial of women skills are reflected in the slow or lack of promotion of women to decision-making positions.

However, these kinds of treatments and attitudes towards women are not openly displayed. As said Msila (2013: 464) "the man is always perceived superior by society irrespective of circumstances". Cultural thoughts strengthen the misogyny of men towards women. This tends to assign systematically leadership according gender lines. That is why Trinidad and Normore (2004) underlined the importance of transcending the cultural norms to avoid a dangerous liaison that may come up between leadership and gender. These biases due to gender stereotypes persist today, especially in rural areas. The attitudes and values associated with gender and leadership shape the beliefs and expectations of workplaces towards their members and stigmatize professional identity. All this constitute therefore women's troubles including how to balance domestic obligations and profession duties.

\section{Balancing family duties and work responsibilities: Women's troubles}

From the findings, it was evident that balancing work and home duties was certainly the prime and major concern of women principals in their position. Based on the findings, the combination of work responsibilities and family obligations is quite challenging for many Ivorian women principals interviewed in this research. Sali revealed, "At times, I got confused with many unexpected tasks, as a result I felt I underperformed". 
That revealed the inconsistency of principals' tasks and could be seen as a cognitive dissonance, which is in agreement with what Wolcott (2003) found, speaking of principals:

There is always something they should or could do that they are not doing, and there is always something they could do more or better. But when you box in a large group of learners of any age for a predetermined number of hours each day and week, there is only a certain amount you can expect to accomplish" ( p. x).

Women principals in this study provided insights into the concern that express the actual experiences as mothers/wives and as leaders. Grzywacz and Carlson (2007) defined work-family balance as the "accomplishment of rolerelated expectations that are negotiated and share between an individual and his or her role-related partners in the work and family domains" (p. 458). Women in this study are torn between family and professional life. They are thus confronted with the issues of availability and mobility. Knowles, Nieuwenhuis and Smit (2009) in their study revealed that it was hard for women mother-educators to juggle their multiple roles of mother, wife and teacher.

How to organize or manage themselves to meet the responsibilities of mothers and wives at once, while responding to work, satisfying the prerogatives of chief. To whom leave the household in case of absence? These are some of the daily trouble and concerns of women workers, and even more so women bosses. Women leaders in the current study indicated that, unlike men principals, they are committed to handle multiple roles (teaching a class, leading the school and managing the house) while their male colleagues tend to have more time to relax, make less of an effort, and are less stressed than women (Asimaki, Zenzefilis \& Koustourakis, 2016). Actually, women were confronted by constraints, as they seek to balance home life with office demands (Brown, 2004).

From the experiences of most women in this study, it can be argued that caring of children at home, fulfilling their duties as mothers and as spouse, which is still largely attributed to women, remain a persistent challenge for women in the leadership positions. How to achieve a better balance between work and private life without affecting her overall life was thus one of the hardest experiences of women principals in this study. The issue of balancing personal life, children and work requirements is seen as the most common barrier that women face in headship. Women principals felt constrained by a triple role: at home as a mother, at the workplace as a teacher, and as principal at once. Fiath confessed, "family duties weighed on us down and became hindrances in our attempts to move up". Kellerman and Rhode (2007) concurred with that, as they have found that women much time drop leadership roles and focus mainly on their family, which in turn disturb their professional 
career. In the context of Côte d'Ivoire, people expect from women first and foremost to be responsible for the family affairs and managing the home. These social roles attributed to women influence them and bring about pressure and stress in their principalship. The following figure shows clearly the cliché of that reality.

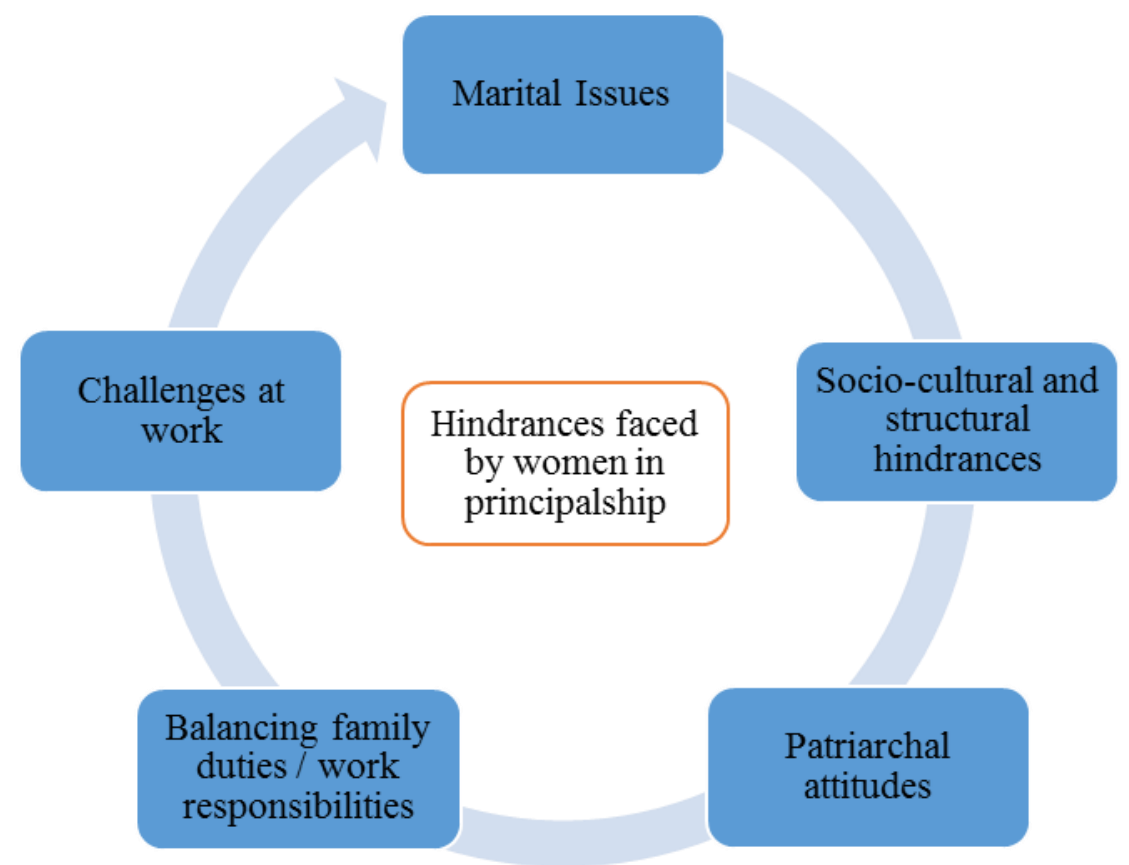

Figure 1: Cliché of Women's hindrances in principalship

Source: Research field data

\section{Overcoming the hurdles: Use of coping strategies}

How women leaders in this study were able to overcome barriers they face is one of the intents formulated to identify the strategies that women principals in this study utilized to surpass obstacles through the pathways. In particular, how women school heads succeed despite barriers and other issues they faced in school leadership positions? It important to note these principals experienced various forms of barriers through their personal and professional life as they related in this study. However, as great and painful as these obstacles appear, they are surmountable. When asked women how women they overcome the barriers they encounter, most mentioned that they have their own ways of dealing with challenges depending on the situations. Bella asserted, "I am naturally patient and a great observer, so when I face situations I just take time and observe what would come out of the situation". As the 
eldest of her siblings, Bella learned how to handle difficult personalities as her parents have played a great and significant role in her approach in dealing with complex situations, especially when tensions or conflicts arose between her little brothers and sisters. She felt that shaped very much her ability of leading people.

Generally, strategies to overcome them include training, experiences and emotional strengths that these women principals used subtly. Furthermore, it can be noticed that they relied on their readiness, communication and sometimes on support from their relatives to overcome the hindrances that they encountered on their pathways. However, special accents are to be put on tips that can reconcile domestic life and professional life, on bypassing prejudices and enhancing self-confidence.

Findings reveal that women principals dealt with issues differently, yet, all together, they thought of themselves as persons who emphasized communication in their relationship with people. Besides, they are very much more proactive and innovative in managing school concerns, as they encouraged parental involvement in the schools and enabled stakeholders and citizens to have a say in the education of their children. Actually, women tried to perform their leadership roles and administrative duties despite stereotypes and undesirable attitudes, especially from men.

To deal with a number of issues and overcome the obstacles, women principals unanimously recognized that they strove to approach them with their own ways. Dany asserted, "if we want to progress, we need to initiate changes which bring concrete results". Fiath further added, "we should not be afraid to think and lead differently". Women leaders believe that they need to train themselves on "deep listening" and remain themselves as much as possible so that they can really understand what's going on and have control over everything. Besides, women principals have to manage the social, structural and instructional matters within their schools that require them to put much attention on every details and deal with the most complex situations such as the schoolchildren's learning difficulties or difficult teachers, which in turn shape their experiences and competencies.

This is in line with what Ghaus-Kelley (2014) revealed in her study. She found that despite the difficulties of their positions, women CEOs' leadership practice strengthened their beliefs, commitments, and leadership abilities. He also noted that these women leaders viewed leadership as an allencompassing lifestyle, a worthy and righteous cause, and perceived their lifetime commitment as a higher calling

There is no doubt about their ability to run their schools. However, the styles of their leadership were influenced by the actual situation depending on the nature of the problems they faced and the goal they targeted. Bella saw herself as more democratic than autocratic while Dany said, 
I used to be myself when I am working ...I keep in my mind I am working with people like me...so I just remain natural as possible and I try to focus on the tasks. When I was vice-principal I worked under a male principal for five years. I used to talk with some of my male colleagues when we meet. From our meetings and discussions, I experienced how men usually perform in leadership positions. I do not think men and women lead in the same way in the primary schools. Also, I think women have something different which is part of their nature.

This perception is in the same line with what some authors (Rigg \& Sparrow, 1994; Brinia, 2012) have demonstrated. In fact, theses scholars showed that leadership characteristics of primary school principals are described as emotionality, sensitivity, expressiveness, cooperation, intuition, tactfulness and receptiveness to ideas. Other studies have attested that women usually became teachers because they like working with children.

\section{Conclusion}

In summary, it is clear that a cross section of factors affect women principals in their leadership role. Actually, women principals experienced challenges that embraced cultural and structural entrenchments, and workhome conflicts, which constitute the main barriers affecting women and their headship in school management positions. Female principals face many hindrances that related to gender role stereotypes and discrimination. This is because, mostly as per the expectations of the society, women are perceived and deemed to hold the subordinate place/position while male holding the leading role. Yet, in Ivorian context it's used to say "derrière un grand homme se trouve une grande dame", meaning behind a great man is always a great lady, and more specifically meaning that the woman is the true support of the man.

Those findings are quite significant and heuristic due to their implications for policy-making on gender and women in educational leadership roles. Thus the study mapped out the hard experiences and difficulties of women principals to create an awareness of the importance of women's experiences in their leadership roles, in particular their personal and professional life. From findings based on the women principals' narrative stories, it was clear that women principals had to cope with a number of challenges and prejudices that persisted in their principalship. Despite a number of hurdles, these Ivorian women principals performed as they can. 


\section{References:}

1. Assie-Lumumba, N.T. (1996). Les Africaines dans la politique: Femmes Baoulé de Côte d'Ivoire. Paris: L'Harmattan.

2. Asimaki, A., Zenzefilis, V. \& Koustourakis, G. (2016). The Access and Development of Female Academics in the University Field in Greece: University of Patras Case Study. Open Journal of Social Sciences, 4, 150-162. http://dx.doi.org/10.4236/jss.2016.43021

3. Brinia, V. (2012). Men vs. Women; educational leadership in primary schools Greece: an empirical study. International Journal of Educational Management, 26 (2), 175-191.

4. https://doi.org/10.1108/09513541211201988

5. Brown, H. E. L. (2004). Barriers to women in educational leadership roles in Montana. Doctoral Dissertation. Bozeman, Montana: Montana State University-Bozeman.

6. Coleman, M. (2002). Women as headteachers: Striking the balance. Stoke on Trent: Trentham Books.

7. Coronel, M. J., Moreno, E., \& Carrasco, M. J. (2010). Work-family Conflicts and the Organizational Work Culture as Barriers to Women. Educational Managers. Gender, work \& Organization, 17(2), 219-239

8. https://doi.org/10.1111/j.1468-0432.2009.00463.x

9. Creswell, J. W. (2013). Qualitative inquiry and research design: Choosing among five approaches. (3rd ed). Thousand Oaks: Sage.

10. Davies, L. (1998). Democratic practice, gender and school management. In P. Drake \& P. Owen (Eds.), Gender and management issues in education: An international perspective. Stoke on Trent: Trentham Books.

11. Hussain, B., \& Asad, A. Z. (2012). A Critique on Feminist Research Methodology. Journal of Politics and Law, 5(4). http://dx.doi.org/10.5539/jpl.v5n4p202

12. Frisby, W., Maguire, P., \& Reid, C. (2009). The ' $f$ ' word has everything to do with it. How feminist theories inform action research. Action Research, 7(1), 13-29.

13. Klenke, K. (1996). Women and leadership: A contextual perspective. New York: Springer.

14. Gaus, N. (2011). Women and school leadership: Factors deterring female teachers from holding principals positions at elementary schools in Makassar. Advancing women in leadership, 31, 175-188.

15. Ghaus-Kelley, H. (2014). Exploring the critical learning moments of women community college executives: A phenomenological study of 
transformative educational leadership practices. (Doctoral Thesis). California State University, Northridge.

16. Gilligan, C. (1982). In a Different Voice: Psychological theory and Women's

17. Development. Cambridge: Harvard University Press.

18. Grzywacz, J. G., \& Carlson, D. S. (2007). Conceptualizing workfamily balance: Implications for practice and research [Special edition]. Advances in Developing Human Resources, 9, 455-471. http://dx.doi.org/10.1177/1523422307305487

19. Hale, S. (2012). Memory work as resistance: Eritrean and Sudanese women in conflicto zones. Dissent: The Politics and Poetics of Women's Resistance. Special Issue of Comparative Studies of South Asia, Africa and the Middle East, Shahrzad Mojab, 32(2), 429-436. http://dx. doi: 10.1215/1089201x-1629025

20. Harel-Giasson, F., \& Marchis-Mouren, M. (1991). Les femmes interpellent l'Université. Montréal: Écoles des Hautes Études Commerciales.

21. Hesse-Biber, S. N. (2012). Feminist research: Exploring, interrogating, and transforming the interconnections of epistemology, methodology, and method. In S. Hesse-Biber (Ed.). Handbook of feminist research: Theory and praxis. (2nd ed.). pp. 2-27). Thousand Oaks, CA: SAGE Publications. http://dx.doi.org/10.4135/9781483384740.n1

22. Kellerman, B., \& Rhode, D. L. (Editors). (2007). Women and Leadership: The State of Play and Strategies for Change. Foreword by Sandra Day O'Connor (Ret.). Jossey-Bass.

23. MoE. (2017). Ministère de l'Éducation National. Données Statistiques de la Direction des Stratégies de la Planification et des Statistiques (DSPS). Availavble at http://www.mendpes.org/new/index.php

24. Mollel, N., \& Tshabanbu, I. (2014). Women in Educational Leadership: Conceptualizing Gender Perceptions in Tanzanian Schools. Educational Research International, 3(4), 46-54.

25. Moreau, C. (2014). Rapport de la Côte d'Ivoire sur la mise en ouvre du programme d'action de Beijing vingt ans après. Ministère de la Solidarité, de la Famille, de la Femme et de l'Enfant. République de Côte d'Ivoire. Retrieved from https://www.uneca.org/sites/default/files/uploadeddocuments/Beijing20/NationalReviews/cote_divoire_beijing_review_ report_0.pdf

26. Msila, V. (2013). Obstacles and Opportunities in Women School Leadership. International Journal of Educational Sciences. $\begin{array}{llll}\text { Retrieved } & \text { July, } & 31 & 2017\end{array}$ 
https://www.academia.edu/4888503/Obstacles_and_Opportunities_in _Women_School_Leadership_A_Literature_Study

27. Oyeniran, R., \& Bonjah, A. I. (2018). Women's leadership experiences: A study of Ivorian Women Primary School principals. Journal of Educational Issues, 4(1),148-173 https://doi.org/10.5296/jei.v4i1.13042

28. Oyeniran, R. (2018). Women Educational Leaders in Principalship: Exploring the Lived Experiences of Women Heading Primary Schools in Côte d'Ivoire. International Journal of Contemporary Education, 1(1), 36-51. https://doi.org/10.11114/ijce.v1i1.3209

29. Reinharz, S. (1992). Feminist Methods in Social Research. New York: Oxford Press.

30. Rigg, C., \& Sparrow, J. (1994). 'Gender, diversity and working styles", Women in Management Review, 9(1), 9-1. https://doi.org/10.1108/09649429410050971

31. Touré, T. D., Kouassi, K. S., Lagou, H., Dahoure, A. D., \& Fofana, L. (2017, March 21). La pace de la femme dans nos société ou alors la représentativité de la femme dans les sphères politiques et de décision. [Television broadcast]. In Radio Television Ivoirienne (RTI) (Producer), Le Grand Débat. Côte d'Ivoire, Abidjan : RTI1.

32. Trinidad, C., \& Normore, A. H. (2005). Leadership and gender: a dangerous liaison? Leadership \& Organization Development Journal, 26(7), 574-590. http://dx.doi.org/ 10.1108/01437730510624601

33. Wolcott, H. F. (2003). The man in the principal's office. An Ethnography. Updated Edition. Altamira Press.

34. Yin, R. K. (2014). Case Study Research. Design and Methods. (5th Ed.). SAGE Publications, Inc. 